\title{
ÖVES LÉGRUGÓTERMÉKEK GYÁRTÁSÁNAK FEJLESZTÉSE
}

\section{DEVELOPMENT IN MANUFACTURING OF BELTED AIR SPRING}

\author{
Kiss Gábor József, ${ }^{1}$ Szigeti Ferenc, ${ }^{2}$ Gergely Dezső ${ }^{3}$ \\ Nyíregyházi Egyetem, Müszaki és Agrártudományi Intézet, Müszaki Alapozó, Fizika és Gépgyártástechno- \\ lógia Tanszék, Nyíregyháza, Magyarország \\ ${ }^{1}$ kissgaborjozsef97@gmail.com \\ ${ }^{2}$ szigeti.ferenc@nye.hu \\ ${ }^{3}$ dezso.gergely@nye.hu
}

\begin{abstract}
Nowadays, due to increasing environmental regulations, public transport is developing rapidly. Therefore, the companies who manufacture railway fittings have to keep up. As a result, factories need to develop and expand their capacity by modernizing existing machines and installing new machines. The author is involved in this capacity expansion, at ContiTech Hungary Ltd, where production of the rail belted air spring had to be increased. In order to do this, improvements were made to the structure drum to build the carcass, for which two suggestions were made regarding the fold back unit. Other goals are the improvement of the air spring and the development of ergonomics.
\end{abstract}

Keywords: train air spring, bellow production, capacitive improvement.

\section{Összefoglalás}

Az egyre szigorodó környezetvédelmi szabályok miatt a tömegközlekedés rohamos léptekben fejlődik, ezért a vasúti szerelvényeket gyártó cégeknek is újabb fejlesztéseket kell bevezetniük. Ennek következtében a jármüipari beszállítóknak a meglévő gépek korszerűsítésével és új gépek beüzemelésével kell fejleszteniük a kapacitásaikat. Egy ilyen kapacitásbővítésben vettem én is részt a ContiTech Magyarország Kft.-nél, ahol az öves vasúti légrugó gyártásának kapacitását kellett növelni. Ennek érdekében a karkasz felépítéséhez szükséges félépítődobra készítettem el fejlesztéseket. Két javaslatot dolgoztam ki a berendezés visszahajtó egységén. A fejlesztéssel további céljaim között szerepelt a légrugó minőségének javítása és az operátorok fizikai terhelésének csökkentése.

Kulcsszavak: vasúti légrugó, membrán gyártás, kapacitásbővítés.

\section{Bevezető}

Vasúti légrugókkal a nagy vízszintes irányú erőhatásokat és rándulásokat csillapítjuk. A légrugó utazás közben elnyeli a pálya egyenletlenségeiből adódóan fellépő rezgéseket, mérsékli a dinamikus erőhatásokat, ezáltal nő az utazási komfortérzet. Függőleges irányú mozgása elhanyagolható, erre a célra még megmaradtak a hagyományos spirálrugók. Ezen rendszerek összeépítéséből áll össze egy korszerü forgóalváz (1. ábra).

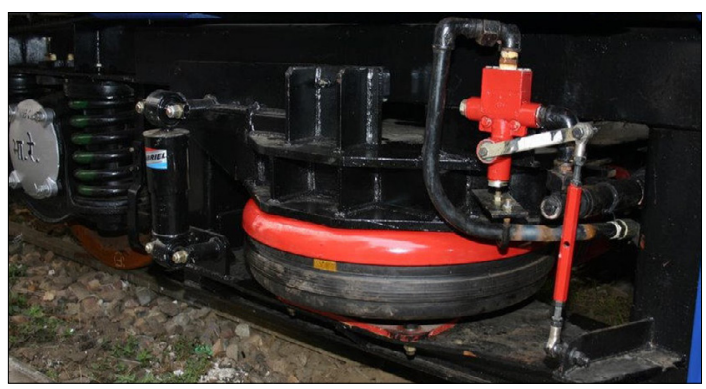

1. ábra. Spirál és öves vasúti légrugóval szerelt vasúti kocsi forgóváza [1] 


\section{Felépítődob bemutatása}

A gyártási kapacitás bővítésének igénye az öves vasúti légrugó termékcsaládnál merült fel, ezért a fejlesztéseket ennek a típusnak a gyártásához szükséges felépítődobokra vonatkozóan végeztem el (2. ábra).

A felépítődob működése: a felépítődob egy kónuszos adapterrel rögzíthető a felépítőgéphez. Rögzítés során oda kell figyelni a levegőcsatlakozók helyzetére, amelyek a felépítőgép adaptertengelyében és a felépítőgép rögzítőtárcsáján helyezkednek el. Ha megfelelően rögzítettük a dobot, akkor a felépítőgép kezelőfelületén keresztül tudjuk szabályozni a két levegőtáplálást. Az egyik csatlakozással a szegmensnyitó balgot tudjuk müködtetni (lásd a 3. ábrán), a másik táplálással pedig a karkasz két szélét tudjuk visszahajtani (lásd a 4. ábrán).

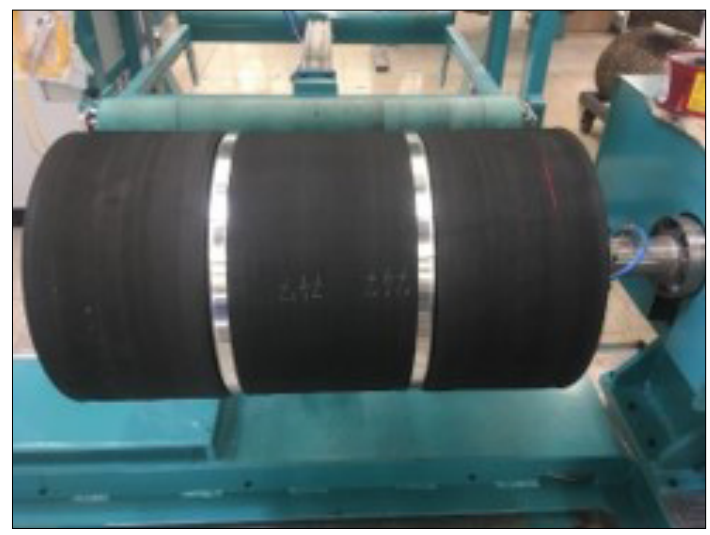

2. ábra. Felépítődob

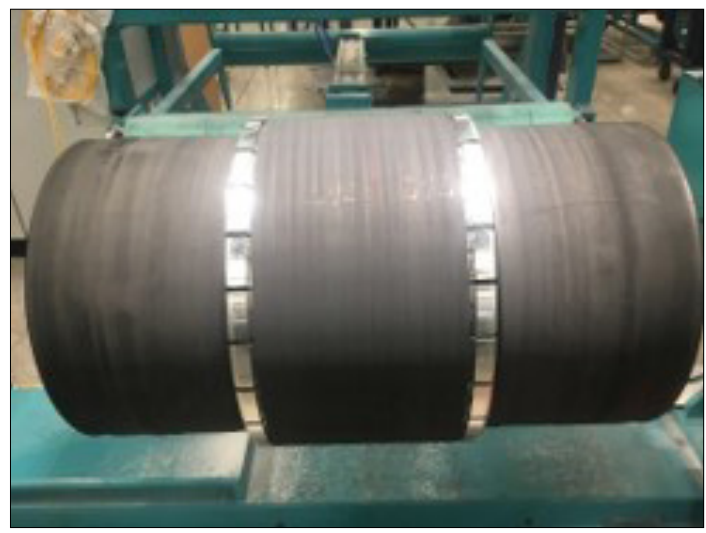

3. ábra. Nyitott állapotú szegmens

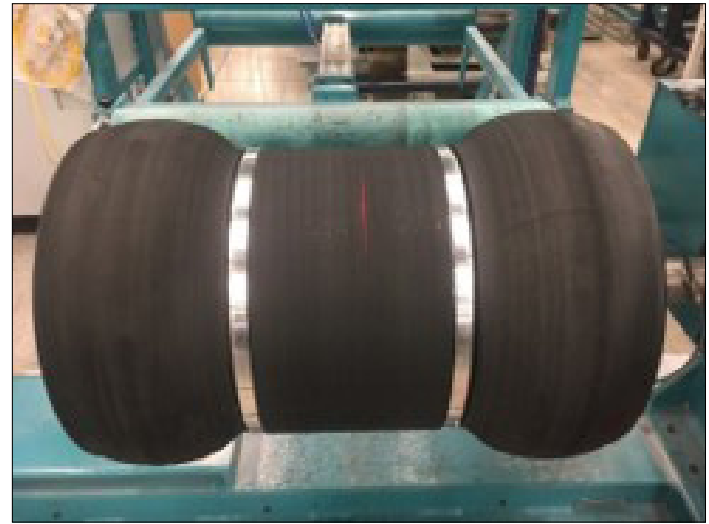

4. ábra. Karkasz szél visszahajtás

\subsection{Jelenlegi karkaszszél-visszahajtás be- mutatása}

A gyártási kapacitás növelése érdekében optimalizálnom kellett a gyártási időket. A felépítés során a membrán szélének a visszahajtása volt a legkritikusabb pont. Jelenleg két egykamrás balgot használnak a visszahajtásra, ezt fejlesztettem úgy, hogy a lehető legkevesebb emberi munkára legyen szükség, és ezáltal a gyártási folyamat gyorsabb legyen.

A 5. ábrán látható, hogy jelenleg milyen mértékben tudjuk visszahajtani a meglévő visszahajtó egységgel a karkasz szélét. A 6. ábrán pedig látható, hogy a dolgozó két kezével tudja csak teljesen visszahajtani a membrán szélét, ami egy műszak alatt eléggé megterheli az operátor ujjait

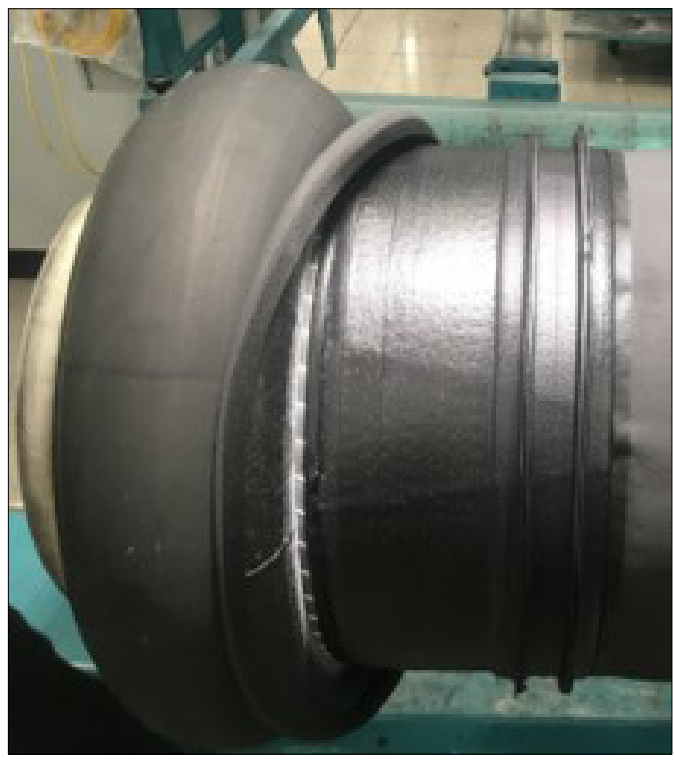

5. ábra. Előhajtás balggal 


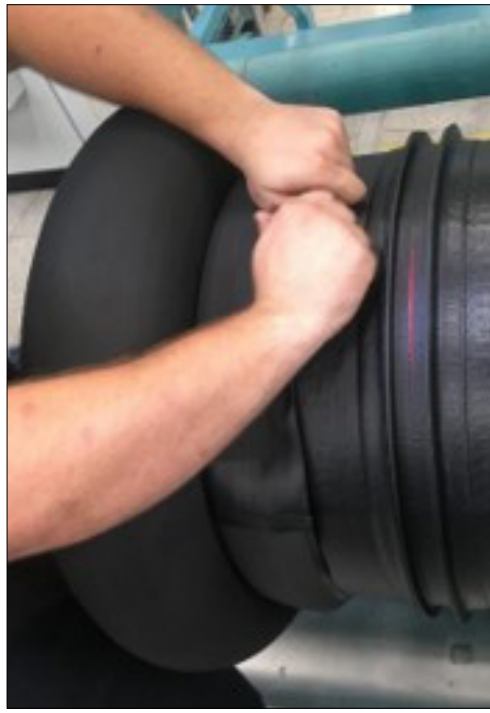

6. ábra. Visszahajtás kézzel

\section{Duplabalgos verzió}

Ebben a fejezetben bemutatom a duplabalgos egység szerkezetét, felvázolom a működtetéséhez szükséges energiaellátást, majd ismertetem a gumielemek gyártásához szükséges felépítődobokat és a rajtuk felépített balgokat.

Az 7. ábrán látható a duplabalgos verzió háromdimenziós modellje. A könnyebb szemléltetés érdekében minden alkatrésznek különböző színt adtam, a két visszahajtó balgot kivéve

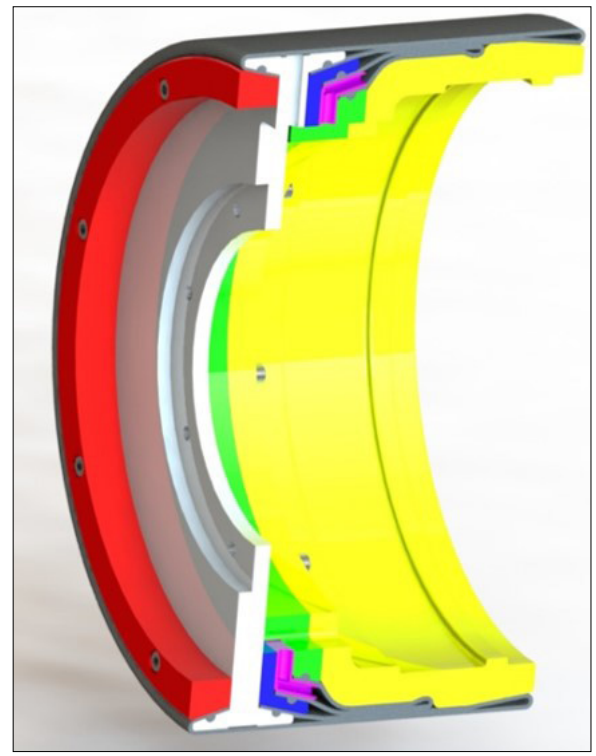

7. ábra. Duplabalgos visszahajtó egység

\subsection{Duplabalgos visszahajtó egység szerke- zete}

Az 8. ábrán látható, szürkével jelölt munkadarab a központi alkatrész. A pirossal, kékkel, lilával és zölddel jelölt alkatrészek a kúpos balgszorítók. Sárgával pedig a danamid adaptert jelöltem.

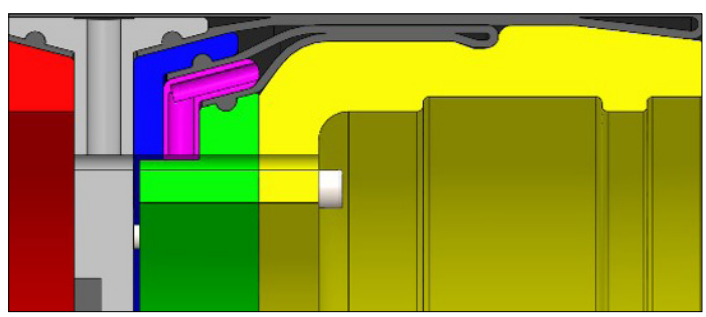

8. ábra. Duplabalgos visszahajtó egység szerkezete

A tervezés során figyelembe vettem az alkatrészek funkcióját, így egyedül a központi alkatrész anyaga lett acél, amely közvetlenül kapcsolódik a felépítődob tengelyén elhelyezett kúpos szorítóhoz. Ezen alkatrészhez kapcsolódnak a kúpos balgszorítók és az általuk közrefogott balgok, továbbá a danamid adapter. A kúpos balgszorító adapterek anyaga alumínium, mivel funkciójukat teljes mértékben ellátják, és ezzel súlyt tudunk csökkenteni, ami nagyon fontos a felépítődoboknál azért, hogy ne terheljék túl a felépítőgépet. Az alumínium hátránya viszont az, hogy a szorítókban elhelyezett menetek hamar károsodnának szerelés során, ezért az összes alkarészt a központi elemen rögzítem [2].

Tervezés során szintén nagy figyelmet kell fordítani a visszahajtó egység külső átmérőjére, amely nem lehet nagyobb 440 mm-nél, mivel akkor a karkaszt nehezen vagy egyáltalán nem lehetne eltávolítani a dobról. Az ábrán látható balgoknál megfigyelhető, hogy a visszahajtás tövénél egy légüres tér képződik, ezt szándékosan ábrázoltam így, mert a már meglévő dobok alapján ez egy tapasztalt viselkedése a balgoknak. Ezt a danamid adapter kikönnyítésével tudjuk kompenzálni.

\subsection{Energiaellátás}

A kapacitásbővítés során telepítésre került egy új felépítőgép, amely lehetővé teszi, hogy 2-nél több levegőtáplálást használjunk a felépítődobok működtetéséhez. Jelen esetben 3 csatlakozást kellene igénybe venni, melyből kettőt az új verzió igényelne. Ahhoz, hogy 3 db táplálást tudjunk használni, a már meglévő felépítőgép-adaptert 
kellene átalakítani vagy egy újat gyártani, ami növelné az üzembe helyezés költségét.

Amennyiben ezt a verziót alkalmazzuk, elveszítjük a gépek közötti átállások lehetőségét esetleges meghibásodás esetén, így ezt a dobot nem tudnánk megfelelően használni a többi felépítőgépen, ha valamilyen okból kifolyólag a legújabb felépítőgép meghibásodna.

A 8. ábrán megfigyelhető, hogy a nagyobb balg a központi adapternél kapja a sürített levegőt, a kisebbik balg pedig a lila színnel jelölt kúpos balgszorítón keresztül.

\subsection{Balg}

A balgoknak két típusát különböztetjük meg. Az egyik típusa a vulkanizáláshoz használt alakítóbalg, amely anyagának köszönhetően nem vulkanizálódik ki soha, csak öregedik. Szerkezetileg csak ezt a különleges gumit tartalmazza [3, 4].

Másik típusa a balgoknak a segédfunkciókra alkalmazott gumielemek. Felépítésük hasonló a légrugókéhoz, ugyanúgy légzáró-borító rétegekből és szövetből épülnek fel. A különbség csak az, hogy a segédbalgok mindig az adott feladatra vannak kialakítva, így a formája minden egyes darabnak teljesen eltérő.

A duplabalgos verzióhoz két segédbalg szükséges. Szerkezetük teljesen megegyezik, csak geometriai méretekben különböznek egymástól.

\subsection{Balg felépítődob}

A balgok felépítéséhez két darab dobra van szükségünk. A 8. ábrán látható, hogy a balgperem átmérői nem egyeznek meg. Felépítésüket csak kúpos és egy hengeres dobon tudnánk elvégezni. A kúpos dob gyártása nagymértékben megnövelné a költségeket.

\section{Ikerbalgos megoldás}

Ebben a fejezetben a második fejlesztési javaslatomat ismertetem, ami a 9. ábrán látható.

\subsection{Az ikerbalgos egység szerkezete}

Az ikerbalgos megoldás müködtetéséhez szükséges alkatrészek kevésbé bonyolultak, mint az előző verzióban, és kevesebb alkatrész szükséges az összeállításához, mivel csak két helyen kell rögzíteni a balgot az egységhez.

Továbbá csökkentettem a visszahajtó egység hosszát $40 \mathrm{~mm}$-el, így anyagot tudunk megspórolni úgy, hogy a szerkezet még elég stabil marad. Ezenkívül a felépítéshez is elegendő hely marad,

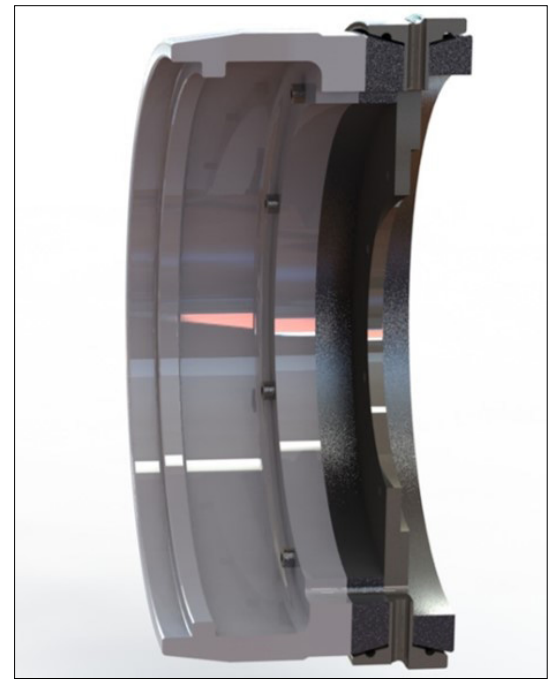

9. ábra. Ikerbalgos megoldás

és ezzel a módosítással még súlyt is tudunk csökkenteni. Mindezeken felül, a balgok élettartamát is növeljük, mivel így kisebb az esélye annak, hogy a dolgozók kiszúrják azt.

\subsection{Az ikerbalgos megoldás előnyei}

A visszahajtó egység fejlesztésével célom a gyártási idő csökkentése. Jelenleg kézzel kell visszahajtani külön-külön mindkét oldalt, ami időigényes. Azzal, hogy balgokkal hajtanánk vissza a membrán szélét, időt tudnánk spórolni.

Továbbá, ha egységesen minden karkasz szélét a visszahajtó balgokkal hajtanánk vissza, akkor elérnénk, hogy minden egyes visszahajtás mindenhol egységes lenne. Ezzel javulna a membránok minősége, hiszen sokkal szorosabban lenne visszahajtva, és nem maradna a peremkarikáknál levegő. Sőt, az ergonómia is javulna a mostanihoz képest, mivel a dolgozónak nem kellene nagy erőt kifejteni az ujjaival.

\subsection{Balg}

A balg szerkezete a duplabalgos verzióhoz képest sokkal bonyolultabb. Elkészítésekor az alapbalgra még egy balg került felépítésre. A 10. ábrán látható, hogy a második balg lapolása hova és milyen szélességben fog kerülni. A két lapolás (talpalás) között fog elhelyezkedni a lyukasztás, amely biztosítja a két balg közötti levegőáramlást.

A balg felépítése ezen rajz alapján történik. A balgok felépítéséhez egyetlen dobra van szükség. A dob készítésekor két fő méretre kell koncentrálni, az átmérőjére és a peremkarikák tá- 


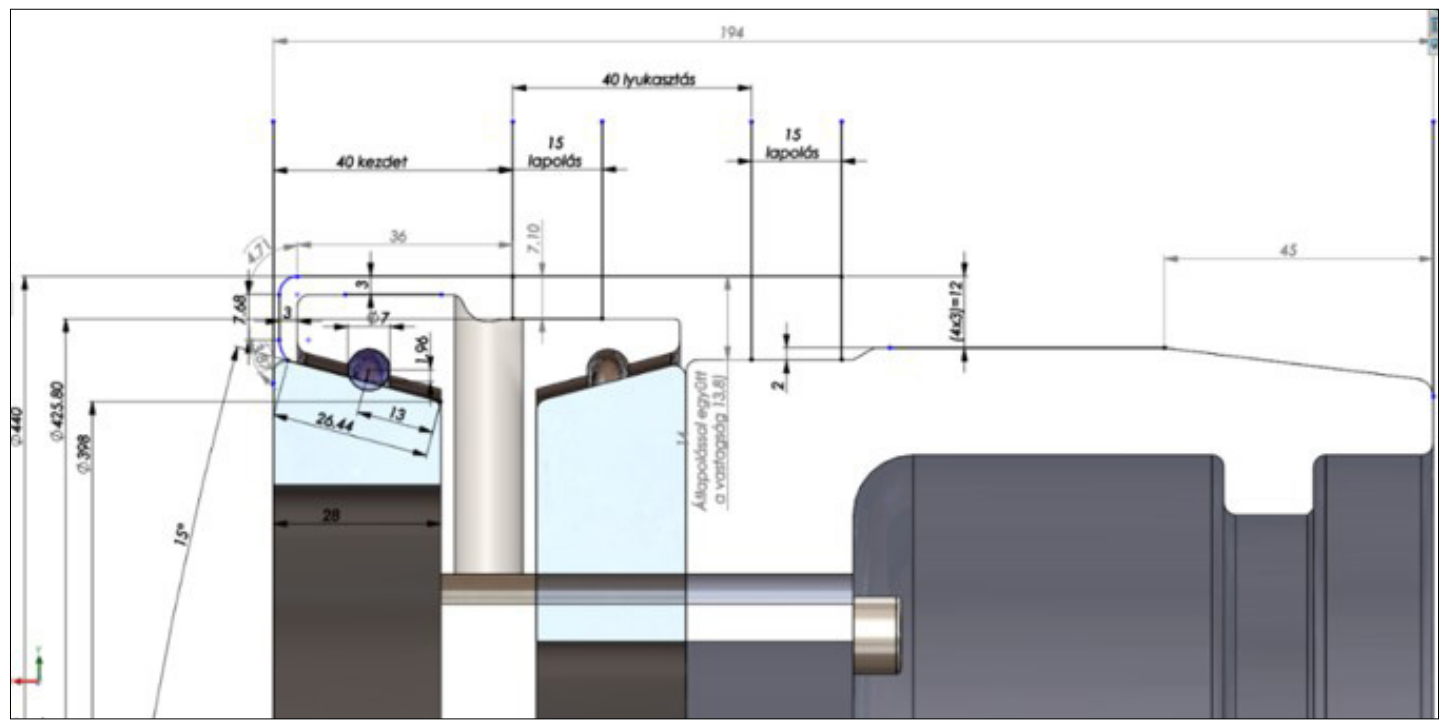

10. ábra. Balg felépítési útmutató

volságára. Ezen méretek meghatározhatók a rajz alapján. Ezenfelül figyelembe kell venni egy 3\%os zsugorodási tényezőt, amelyet még pluszban hozzá kell adni a méretekhez.

\section{A membránszél visszahajtási kísérle- te ikerbalgos egységgel}

Az öveslégrugó-felépítő dob kialakításának köszönhetően lehetőségünk volt végrehajtani egy kísérletet, amelyben teszteltük az ikerbalgos viszszahajtó egység működését, funkcióját.

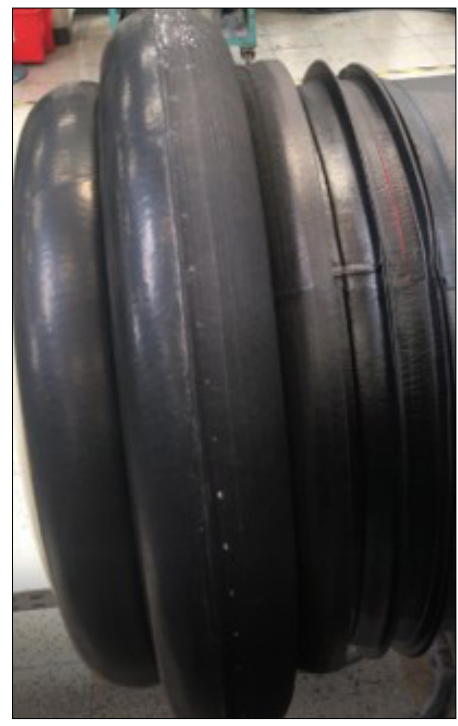

11. ábra. Visszahajtás balggal
A 11. ábrán látható, hogy a karkasz szélvisszahajtása az ikerbalggal történik. Megfigyelhető az ábrán, hogy ezzel az új technikával szinte teljesen vissza tudjuk hajtani a membránok szélét.

Továbbá, a visszahajtások minősége érezhetően jobb, mivel nem marad levegő a visszahajtás tövében. Ez annak köszönhető, hogy a balg teljesen a peremkarika tövétől feszíti a karkaszt a szegmensek szélének, így egy sokkal szorosabb viszszahajtást idéz elő. A 12. ábrán látható, hogy az operátornak már csak rá kell simítania a karkasz szélét.

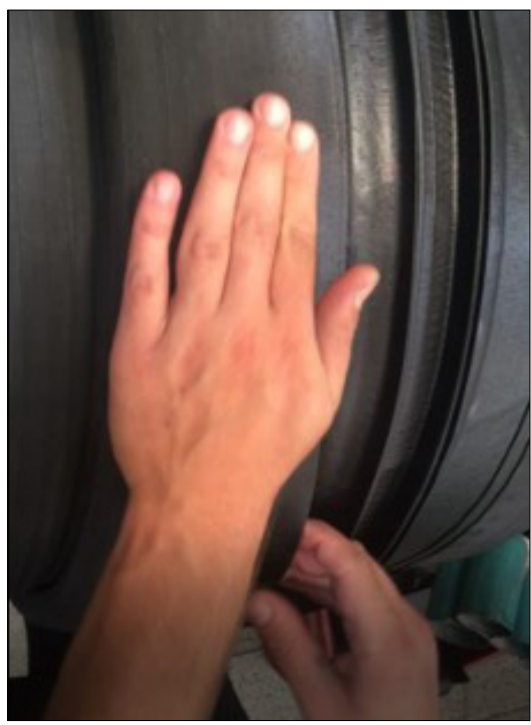

12. ábra. Simítás 


\section{Fejlesztések összehasonlítása}

A megfelelő fejlesztés kiválasztása előtt készítettem a főbb szempontok alapján egy összehasonlítást, amely a 1. táblázatban látható.

A fejlesztések közül az ikerbalgos megoldásra esett a választás kedvezőbb feltételeinek köszönhetően. Az üzem területén már 3 darab felépítődob átalakítása megtörtént, és további dobok kerülnek majd átalakításra.

1. táblázat. Fejlesztések összehasonlítása

\begin{tabular}{|c|c|c|c|}
\hline \multicolumn{2}{|c|}{ Duplabalgos fejlesztés } & \multicolumn{2}{|c|}{ Ikerbalgos fejlesztés } \\
\hline Előnyök & Hátrányok & Előnyök & Hátrányok \\
\hline $\begin{array}{l}\text { Egyszerű } \\
\text { gumielemek }\end{array}$ & $\begin{array}{l}\text { Bonyolult } \\
\text { szerkezet } \\
\text { Nagyobb } \\
\text { tömeg } \\
\text { Bonyolult- } \\
\text { abb szerelés } \\
\text { Két balg } \\
\text { felépítődob } \\
\text { szükséges }\end{array}$ & $\begin{array}{l}\text { Egyszerű } \\
\text { szerkezet } \\
\text { Kisebb tömeg } \\
\text { Egyszerüb- } \\
\text { ben szerel- } \\
\text { hető } \\
\text { Egy balg } \\
\text { felépítődob } \\
\text { szükséges }\end{array}$ & $\begin{array}{l}\text { Bonyolult } \\
\text { gumielem }\end{array}$ \\
\hline
\end{tabular}

\section{7. Összefoglalás}

A vasúti légrugók gyártásának kapacitásbővítése érdekében fejlesztéseket végeztem a felépítéshez szükséges felépítődob karkaszvisszahajtó egységén. Két megoldást dolgoztam ki, amelyek közül az ikerbalgos verzióra esett a választás. Ezzel a megoldással a már elvégzett kísérletek alapján növelni tudom a visszahajtás hatékonyságát, minőségét és mindezek mellett csökkenteni lehet a manuális munkát. Az eredmények láttán további felépítődobok is átalakításra fognak kerülni.

\section{Szakifejezések magyarázata}

A dolgozatomban használok néhány speciális gumiipari szakkifejezést, ezeket szeretném röviden elmagyarázni [3, 4].

Karkasz: A felépített nyers termék vulkanizálás előtti állapota.

Felépítés: a termék konfekcionálása, egy hengeres felületre feltekerve a nyers gumit és a szilárdsághordozó szövetet, majd az így kapott cső mindkét oldalát visszahajtjuk, rugalmas vagy fix drótból készült karikára. A felépítés lehet egyvagy kétfázisú.

Egyfázisúnál a terméket komplettre építjük, kétfázisúnál először egy csövet építünk, majd egy másik gépen tesszük fel a peremkarikákat a megfelelő pozícióba. A felépített gumielem: Légzáró (belső gumiréteg (14. ábra)) - Szilárdsághordozó (2 vagy több gumizott szövetréteg (13. ábra)) - Borító (külső gumiréteg (14. ábra)) - Peremdrótok.

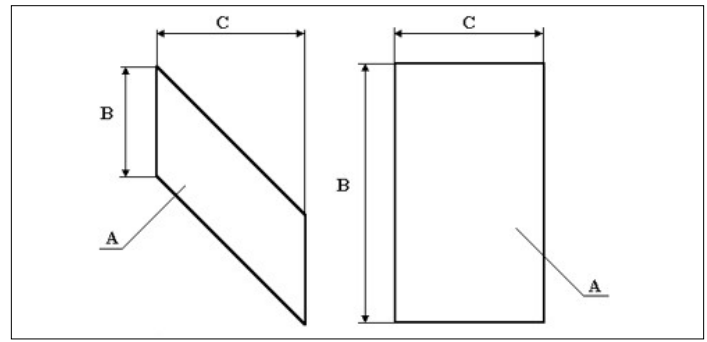

13. ábra. Szövetbetét

14. ábra. Légzáró és borító betét

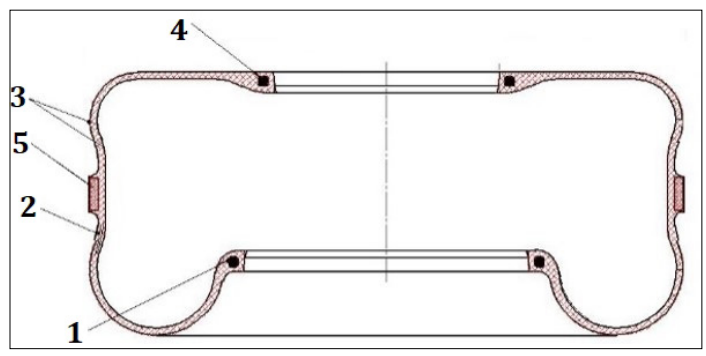

15. ábra. 1. Nagyperemdrót; 2. Szövetek; 3. Légzáró-borító; 4. Kisperem drót; 5. Gumirozott övdrót

Felépítődob: Hengeres eszköz, amire a nyers félkész terméket feltekerjük.

Balg (zsák): két fajtája van:

Vulkanizáló balg: Nyúlásra képes gumitermék, 4-10 mm falvastagsággal, több méretben készül, nehezen vulkanizáló kaucsukból (bróm-butil) így több termék kivulkanizálására alkalmas. Funkciója, hogy a terméket belülről a forma falához nyomja, ezzel biztosítva a vulkanizáláshoz szükséges nyomást.

Felépítő balg: Nyúlásra képes textil-gumi kombináció, amit a felépítődob végére szerelve segít a karkasz végének visszahajtásában.

Vulkanizálás: Vulkanizálásnak nevezzük mindazokat a folyamatokat, amelyekben a képlékeny, viszkoelasztikus viselkedésű kaucsukkeveréket elasztikus gumivá alakítjuk át.

Öves vasúti légrugó: A membrán közepe dróttal erősített, így nagyobb terhelést képes felvenni, helyigény növekedés nélkül (15. ábra).

\section{Szakirodalmi hivatkozások}

[1] https://indiarailinfo.com/blog/post/489191/16 Letöltés: 2019.11.21

[2] Fenyvessy T., Fuchs R., Gürtler M., Plósz A.: Múszaki Táblázatok. TCS Media Kft, Budapest, 2015.

[3] Bartha Z.: Gumiipari kézikönyv. I. Taurus-OMIKK, Budapest, 1988.

[4] Bartha Z.: Gumiipari kézikönyv. II. Taurus-OMIKK, Budapest, 1989. 